Reprod. Nutr. Dévelop., 1982, 22 (2), 405-412.

\title{
Changes in the number of germ cells in the gonads of the rainbow trout (Salmo gairdneri) during the first 10 post-hatching weeks
}

\author{
Claire LEBRUN, R. BILLARD, B. JALABERT (*) \\ with the technical assistance of Anne-Marie ESCAFFRE and Chantal CAUTY (*) \\ Laboratoire de Physiologie des Poissons, I.N.R.A. \\ 78350 Jouy-en-Josas, France. \\ (*) Campus de Beaulieu, 35042 Rennes Cedex, France.
}

\begin{abstract}
Summary. The number of germ cells in fry gonads was determined from histological sections sampled periodically over a 10 -week post-hatching period. Several successive types of germ cells were identified : primordial germ cells (PGC), two kinds of gonocytes $\left(G_{1}\right.$ and $\mathrm{G}_{2}$ ) and all the stages of female meiotic prophase. The mean diameters are shown in table 1 .

The number of germ cells increased regularly from $47 \pm 35$ (SD) after hatching (PGC) to $166 \pm 25$ at 2 post-hatching weeks $\left(G_{1}\right)$. At 5 post-hatching weeks, two groups of fish could be distinguished by the number of their germ cells $\left(G_{2}\right)$ - one group had less than 926 cells and the other more than 1577 - and by their gonadal morphology (filiform or with an enlarged anterior part due to germ cell concentration). At 6 post-hatching weeks, the ovary differentiated with organization of the ovarian lamellae and the appearance of oocytes in meiotic prophase (4 out of 10 trout). The gonads of the other fish stayed at the indifferent stage. The number of germ cells was significantly higher in female-type gonads (6 $335 \pm 3558$ ) than in indifferent gonads (1 $696 \pm 467)$. The situation was the same at 8 to 10 weeks.
\end{abstract}

\section{Introduction.}

Changes in the number of germ cells in the gonads of lower vertebrates after hatching have been studied in cyclostomes and reviewed by Hardisty (1967) ; the very limited information on teleost fish mainly concerns Oryzias latipes (Gamo, 1961 ; Satoh and Egami, 1972 ; Quirk and Hamilton, 1973). The present work reports the numerical changes in various types of germ cells in the gonads of rainbow trout (Salmo gairdneri) fry during the first 10 post-hatching weeks.

\section{Material and methods.}

Eggs, taken in a fish-farm and brought to the laboratory at the eyed stage, were incubated at $10^{\circ} \mathrm{C}$. A maximal number of them hatched on March 30, and 
all the fish hatched after 4 days. The average hatching time was March 30. Immediately after hatching the fry were put into 140-liter tanks, each containing 500 fry. The vitelline was resorbed 18 to 20 days later and the fry were fed pellets (Aqualim) 2 or 3 times per day at a daily rate of 5 p. 100 of body weight. The mean weekly temperature was $10^{\circ} \mathrm{C}$ at the beginning of the experiment and reached $15{ }^{\circ} \mathrm{C}$ at the end (fig. 1). The number of degree-days (mean daily temperature $\times$ number of days) is given in table 2 .

The water was recycled, and the dissolved oxygen, nitrites and $\mathrm{pH}$ were controlled weekly. After 10 weeks, the survival rate was about 70 p. 100.

On March 30 and 2, 5, 6, 8 and 10 weeks afterwards, some fry were anesthetized, killed by decapitation and fixed in toto in Bouin-Hollande. The 7- $\mu \mathrm{m}$ longitudinal sections were stained with Regaud Hematoxylin, Orange $G$ and aniline blue. The mean diameter (D) of the germ cell and of its nucleus was determined by measuring the greatest diameter and the perpendicular one. About 30 to 50 cells per fish were measured. The total number of germ cells was estimated by counting all the nuclei observed in both gonads on one section out of 8. The result was corrected using the formula of Abercrombie (1946): $\mathrm{N}_{\mathrm{S}}=\mathrm{n} / \mathrm{t}+\mathrm{D}$, where $\mathrm{n}=$ the number of nuclear sections, $\mathrm{t}=$ histological section thickness $(7 \mu \mathrm{m})$ and $D=$ nuclear diameter. $N_{S}$ gave the number of cells per histological section and the total number $(N)$ was found by multiplying $N_{S}$ by the number of histological sections. The results, shown in the table and graph, were compared by variance analysis.

\section{Results.}

The growth of the fry during the experimental period is shown in figure 1 . The morphological changes in the gonads are shown in the plate : at hatching and up to 4 weeks, the gonad consisted of a pair of tiny filaments (PI. 1, 2) attached dorsally to the peritoneal cavity by a mesochorium and lying lateral to the gas bladder. At 5 weeks, the gonads of some fish enlarged more anteriorly (PI. 3), as was also found at 6 weeks when the ovary began to differentiate (PI. 4). The gonads in the other specimens were unchanged (PI. 5).

\section{PLATES 1 to 8}

PI. 1. - Gonad of rainbow trout at hatching with primary germ cell (PGC). $\times 710$. PI. 2. - Gonad at 2 post-hatching weeks (140 degree-days). $\mathrm{M}=$ mitosis ; $\mathrm{PGC}=$ primary germ cell ; $\mathrm{G}_{1}=$ first gonocyte generation. $\times 710$. PI. 3. - Gonad at 5 post-hatching weeks showing anterior gonadal enlargement. $\times 280$. PI. 4. - Female-type gonad at 6 post-hatching weeks showing first sign of ovarian lamella organization (arrow). $\times 710$. PI. 5. - Indifferent gonad at 6 post-hatching weeks (462 degree-days). $\times 710$. Pl. 6. - Detail of first $\left(\mathrm{G}_{1}\right)$ and second $\left(\mathrm{G}_{2}\right)$ generation gonocytes at 4 post-hatching weeks. $\times 1700$. PI. 7. - Detail of ovarian lamellae at 7 post-hatching weeks (563 degree-days) with oocytes in meiotic prophase. $L=$ leptotene $; Z=$ zygotene $; P=$ pachytene. $\times 710$. PI. 8. - Diplotene stage (D) oocyte in a gonad at 10 post-hatching weeks (878 degreedays). $\mathrm{FC}=$ follicular cell. $\times 710$. 


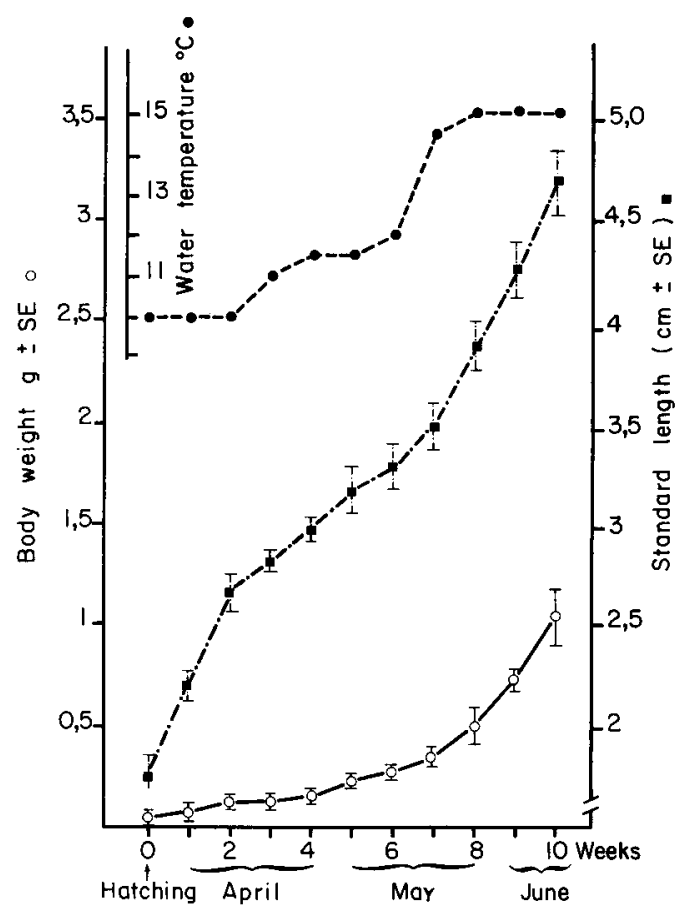

FIG. 1. - Changes in the standard length and body weight of fry during the experiment.

At the top: changes in water temperature.

Several types of germ cells were identified successively in the gonads. At hatching, only one type of germ cell with a large nucleus (cell : $14.3 \pm 0.75 \mu \mathrm{m}$ nucleus : $10 \pm 0.45 \mu \mathrm{m}$ (see table 1) was observed. The nucleus had one nucleolus and fine chromatin filaments. These cells were interpreted as being primary germ cells (PGC). Between weeks 2 and 10, the PGC were found in very small numbers and were not counted. At 2 post-hatching weeks, we identified another type of germ cell in active multiplication $(8.4 \pm 0.34 \mu \mathrm{m}$ for nuclear diameter (PI. 2). Its nucleus was significantly smaller (table 1) and included 2 to 3 nucleoli and small chromatin masses. At 5 weeks, two types of germ cell were identified : one was similar in aspect and size to that described at 2 weeks, and the other was significantly smaller $(7.35 \pm 0.07 \mu \mathrm{m} ; \mathrm{P}<0.001)$ (table 1) with several nucleoli and more dense chromatin (PI. 6). These cells, obviously issued from the PGC, resembled gonocytes $\left(G_{1}\right.$ and $\left.G_{2}\right)$. At 6 weeks, the morphology of $G_{1}$ and $G_{2}$ was similar in differentiated ovaries and indifferent gonads, but the nuclear diameter of $G_{1}$ was significantly greater $(P<0.001)$ in the ovary than in the indifferent gonad (table 1).

The successive stages of germ cells in meiotic prophase were identified in the ovaries ( PI. 7, 8; table 1) at 6 weeks and later. The mean diameter of all the nuclei of the various germ cells measured are compared in figure 2 . The number of germ cells is given in table 2. At hatching, the number of PGC was low : 

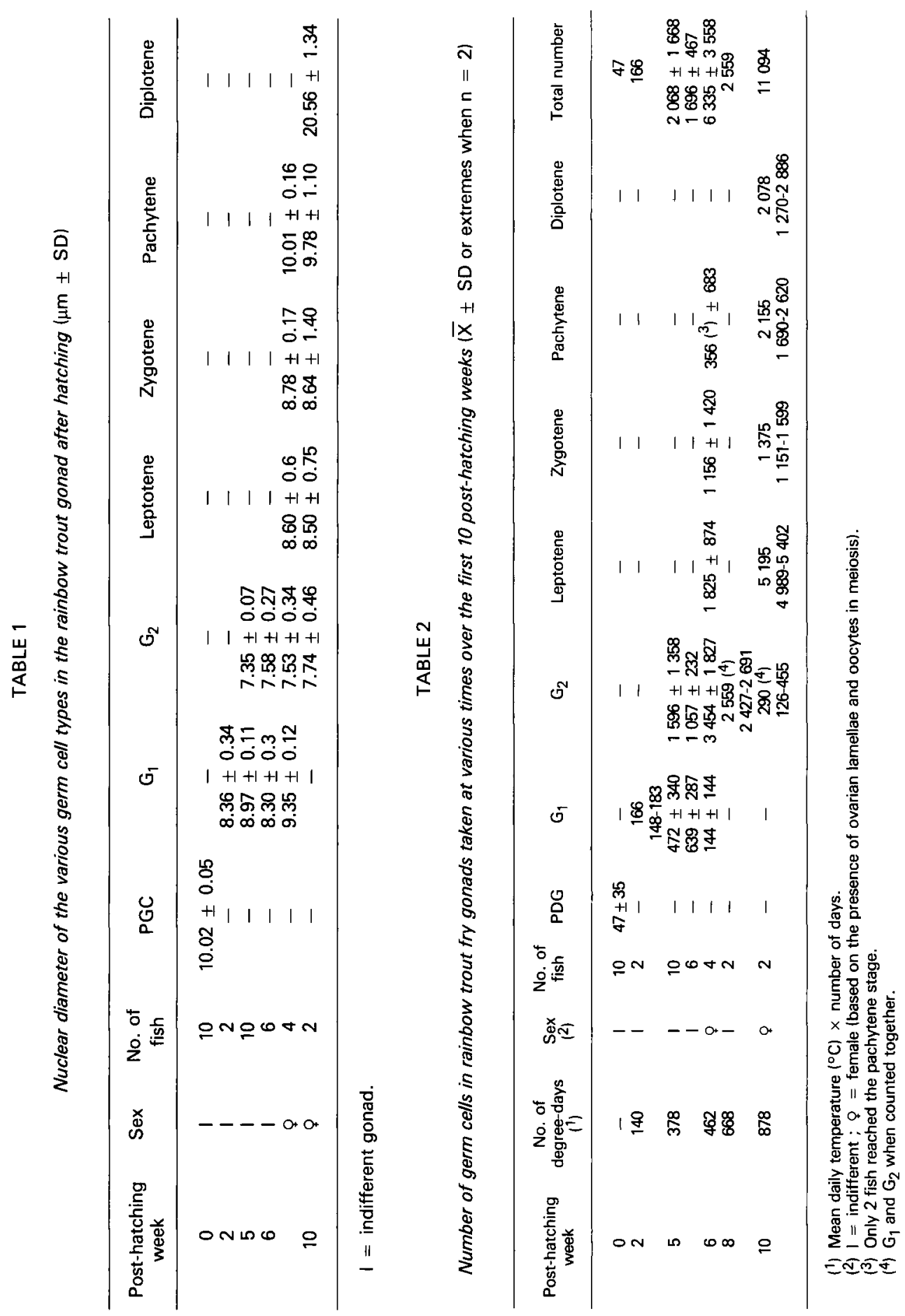

Reproduction, nutrition, développement, $n^{\circ} 2$ 
$47 \pm 35$; extremes 8-132. The number of $G_{1} 2$ weeks later was 166 , indicating that only a few divisions had occurred. The number of $G_{1}$ did not increase subsequently very much, and never exceeded 1000 ; this number seemed lower in newly differentiated ovaries at 6 weeks. The number of $G_{2}$ was quite variable ; at 5 weeks, that variability was high $(\bar{X}=1596 \pm 1358)$, and two groups of fish were distinguished according to their number of $G_{2}$, one having 396-926 $(n=4)$ and the other $1577-5580(n=6)$. These two groups correlated with the morphological differences observed in the gonads. The anterior part of the gonad, where most of the germ cells were found, was enlarged. This gonad contained the highest number of $G_{2}$. The smallest number of $G_{2}$ was found in the filamentlike gonads.

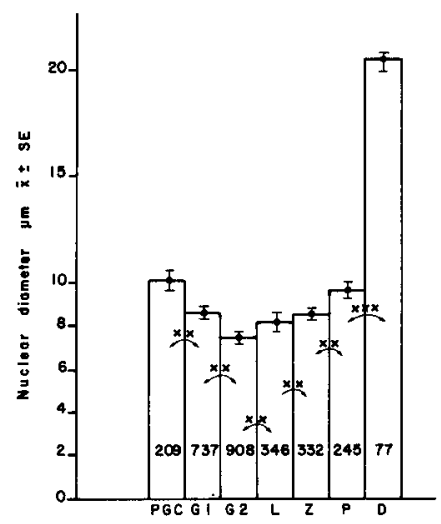

FIG. 2. - Mean nuclear diameter of the various germ cells identified in the gonads between hatching and 10 post-hatching weeks. $\times: \mathrm{P}<0.01 ; \times \times \times: \mathrm{P}<0.001$.

In morphologically differentiated ovaries, $G_{2}$ were actively dividing since the total number of cells in meiotic prophase was very high, exceeding 10000 at 10 weeks.

\section{Discussion.}

The first signs of sexual differentiation in juvenile rainbow trout were found at 5 post-hatching weeks ( 378 degree-days). We divided the fish into two groups according to their total number of germ cells $\left(G_{2}\right)$ and their gross gonadal morphology. In one group, the gonad containing a small number of germ cells $(472 \pm 340)$ remained indifferent. The other group had more germ cells $(1596 \pm 1358)$ concentrated in an enlarged anterior part of the gonad. This anterior enlargement, still observed at 6 post-hatching weeks (462 degree-days), showed the organization of the ovarian lamellae. At 10 weeks, the gonads of some fish were still indifferent, suggesting that they might become male, but this observation requires further investigation. 
These results agree with those of previous studies on rainbow trout in which sexual differentiation occurred at about 600 degree-days post-fertilization (Van den Hurk and Slof, 1981), 2 months after fertilization (Takashima et al., 1980) or shortly after completion of yolk sac resorption (Padoa, 1939).

The number of germ cells in the present study was found to be higher in rainbow trout ovaries than in indifferent gonads. This observation has also been reported in O. keta (Robertson, 1953) and Salmo trutta (Ashby, 1957). The PGC diameter $(14.3 \mu \mathrm{m})$ we found in rainbow trout is less than that reported in the same species by Van den Hurk and Slof (1981) but is within the size range (10$16 \mu \mathrm{m}$ ) reported for fish PGC by Hardisty (1967).

The rather limited number (about 50 ) of germ cells we found at hatching in rainbow trout gonads is comparable with other data on some fish species before sexual differenciation: $12-50$ in Cottus bairdii (Hann, 1927); 100-200 in Platypoecilus (Wolf, 1931) ; 123, 99, 127, 72 in O. latipes (Gamo, 1961 ; Tuzuki et al., 1966 ; Satoh and Egami, 1972 ; Quirk and Hamilton, 1973, respectively), and is also comparable to the number found in most of the other vertebrates (Hardisty, 1967).

Immediately after sexual differentiation, the number of oocytes in our experiment never exceeded 10000 , suggesting that the whole oocyte stock had not yet been formed because the rainbow trout has a fecundity of about 2500 eggs per $\mathrm{kg}$ of body weight (Allen and Sanger, 1960) and produces many more than 10000 eggs during its life-span. Therefore, other oogenetic waves must occur later which probably originate from the $G_{2}$ remaining in the ovaries at 10 weeks.

The number of type A spermatogonia present in the adult male testis has been estimated at $25010^{6}$ (Billard, 1981); this means that the increased number of germ cells corresponds to a very high number of cell divisions (at least 19), occuring before the process of spermatogenesis starts.

Communication présentée au colloque sur la "Sexualisation chez les Vertébrés inférieurs", Banyuls-sur-mer, France, avril 1981.

Reçu en juin 1981.

Accepté en octobre 1981.

Acknowledgements. - This work was supported by the INRA. We wish to thank Ms. Daifuku who translated the manuscript and Ms. Reinaud for fruitful discussion.

Résumé. Le nombre de cellules germinales présentes dans les deux gonades a été établi à partir de sections histologiques sur des alevins prélevés périodiquement après éclosion pendant 10 semaines. L'étude morphologique des cellules germinales fait apparaître une succession de plusieurs types cellulaires: cellules germinales primordiales (PGC), 2 catégories de gonocytes $\left(G_{1}\right.$ et $\left.G_{2}\right)$ et tous les stades de la prophase méiotique femelle. Les diamètres moyens en sont donnés dans le tableau 1. Le nombre de cellules germinales augmente régulièrement ; il est de $47 \pm 35$ (SD) après l'éclosion (PGC) et $166 \pm 25$ à 2 semaines $\left(G_{1}\right)$. A 5 semaines, on peut distinguer deux groupes d'animaux qui diffèrent significativement par le nombre de cellules germinales $\left\langle G_{2}\right)$ lun groupe ayant moins de 
926 cellules et l'autre plus de 1577 ) et la morphologie des gonades (gonades filiformes ou renflées antérieurement où se concentrent les cellules germinales). A 6 semaines l'ovaire se différencie avec organisation des lamelles ovariennes et apparition de la prophase méiotique femelle (4 individus sur 10). Les gonades des autres poissons restent indifférenciées. Le nombre de cellules germinales est significativement plus élevé dans les gonades de type femelle (6 $335 \pm 3558$ ) que dans les gonades indifférenciées (1 $696 \pm 467)$. Cette situation se retrouve à $8-10$ semaines.

\section{References}

ABERCROMBIE M., 1946. Estimation of nuclear population from microtome sections. Anat. Rec., 94, 239-247.

ALLEN G. H., SANGER G. A., 1960. Fecundity of rainbow trout from actual count of eggs. Copeia, $3,260-261$.

ASHBY K. R., 1957. The effect of steroid hormones on the brown trout (Salmo trutta L.) during the period of gonadal differenciation. J. Embryol. exp. Morph., 5, 225-249.

BILLARD R., 1981. A quantitative analysis of spermatogenesis in the trout, Salmo trutta fario (Submitted for publication).

GAMO H., 1961. On the origin of germ cells and formation of gonad primordia in the medaka, Oryzias latipes. Jap. J. Zool., 13, 101-115.

HANN M. W., 1927. The history of the germ cells of Cottus bairdii (Girard). J. Morph., 43, 427-497.

HARDISTY M. W., 1967. The numbers of vertebrate primordial germ cells. Biol. Rev., 42, 265-287.

HURK R. Van den, SLOF G. A., 1981. A morphological and experimental study of gonadal sex differentiation in rainbow trout, Salmo gairdneri. Cell. Tiss. Res., (in press).

PADOA E., 1939. Observations ultérieures sur la différenciation du sexe, normale et modifiée par l'administration d'hormone folliculaire, chez la truie iridée (Salmo irideus). Biomorphosis, 1, 337-354.

QUIRK J. G., HAMILTON J. B., 1973. Numbers of germ cells in known male and female genotypes of vertebrate embryos (Oryzias latipes). Sciences, 180, 963-964.

ROBERTSON J. G., 1953. Sex differentiation in the Pacific salmon, Oncorhynchus keta (Walbaum). Can. J. Zool., 31, 73-79.

SATOH N., EGAMI N., 1972. Sex differentiation of germ cells in the teleost Oryzias latipes, during normal embryonic development. J. Embryol. exp. Morph., 28, 385-395.

TAKASHIMA F., PATINO R., NOMURA M., 1980. Histological studies on the sex differentiation in rainbow trout. Bull. jap. sci. Fish., 46, 1317-1322.

TUZUKI E., EGAMI N., HYODO Y., 1966. Multiplication and sex differentiation of germ cells during development in the medaka, Oryzias latipes. Jap. J. Ichthyol., 8, 177-181.

WOLF L. E., 1931. The history of the germ cells in the teleost, Platypoecilus maculatus. J. Morph., 52, 115-153. 